Savunma Bilimleri Dergisi

The Journal of Defense Sciences

Kasim/Nov 2018, Cilt/Volume 17, Say1/Issue 2.

ISSN (Bas111) : 1303-6831 ISSN (Online): 2148-1776

\title{
İş Bağımsızlığının İşin Kendisinden Duyulan Tatmin Üzerindeki Etkisinde Gelişime Açıklık Kişilik Özelliğinin Aracılık Rolü: Özel Sektörde Bir Uygulama*
}

\author{
İ.Sani MERT**, Mustafa BEKMEZCi*** ve Kemal EROĞLUER****
}

$\ddot{o} z$

Personelin iş tatmininin örgüt için olumlu sonuçlar doğurduğu ilgili yazında tartışılmakta ve iş özelliklerinin iş tatmini konusunda önemli bir unsur olduğu belirtilmektedir. Işs tatmini konusunda, iş özellikleri ile birlikte kişilik özelliklerinin de önemli bir unsur olduğu, dolayısılla bu hususun da dikkate alınmast gerektiği değerlendirilmektedir. Bu kapsamda bu çalışmada, iş özelliklerinden işin bağımsızlığa imkân vermesi boyutunun, iş tatmini boyutlarından işin kendisinden tatmin boyutu üzerindeki etkisi ve gelişime açılklk kişilik özelliğinin aracılık rolünün incelenmesi amaçlanmıştır. Araştırmada işin özellikleri kapsamında, "işin bă̆ımsızlı̆̆a imkân vermesi”; iş tatmini kapsamında, "işin kendisinden tatmin olma"; kişilik kapsamında, "gelişime açı olma" alt boyutları ele alınmıştır. Veriler savunma sanayiinde hizmet sunan özel sektörde çalışan 622 kişiden anket tekniği ile toplanmış ve bunların analizleri yapılmıştır. Elde edilen bulgulara göre; kişiliğin gelişime açık olma boyutunun, iş özelliklerinin iş tatminini yordamasında aracıllk rolü olduğu tespit edilmiştir.

Anahtar Kelimeler: İ̧ş Özellikleri, İş Tatmini, Kişilik, Gelişsime Açıklık.

\footnotetext{
* Bu makalenin ilk versiyonu, 4. Örgütsel Davranış Kongresinde (04-05 Kasım 2016Adana) bildiri olarak sunulmuştur.

** Prof. Dr., Antalya Bilim Üniversitesi, mail:İbrahim.mert@antalya.edu.tr, ORCID:0000-0002-2850-1865

*** Doç.Dr., Toros Üniversitesi, mail:mustafa.bekmezci@ toros.edu.tr, ORCID:0000-0002-1206-690X

**** Dr. Milli Savunma Üniversitesi KHO, mail: kerogluer@kho.edu.tr, ORCID:0000-0002-2456-5140
} 


\title{
The Mediation Role of The Development of Personality Trait in The Effect of Job Independence on Satisfaction in The Work Itself: An Application in The Private Sector
}

\begin{abstract}
It is argued in the literature that the job characteristics is an important factor for job satisfaction which gives positive results for the organization. It has been stated that personality traits has been an important factor for job satisfaction as well as job characteristics then should be taken into consideration for job satisfaction. In this context, in this study, the role of personality traits in the effect of job characteristics on job satisfaction was examined. Within the scope of the study, within the scope of the job characteristics, "the work that allows independence"; within the context of job satisfaction, "satisfaction of the job itself"; within the scope of the personality traits, "openness to development" were taken into consideration as the sub-dimensions. The data were collected via the surveys from 622 employees in the private sector, providing services in the defense industry. According to findings; openness to development plays the mediator role on the effect of the job characteristics on the job satisfaction.
\end{abstract}

Keywords: Job Characteristics, Job Satisfaction, Personality, Openness to Development.

\section{Giriş}

Sosyal yaşamın önemli aktörü olan örgütler, bireylerin kendileri tarafından karşılayamadıkları tüm ihtiyaçlarını karşılamalarına imkân sağlaması yanında onların çalışma ihtiyaçları da dahil olmak üzere pek çok ihtiyaçlarını karşılar. Örgütlerde etkili ve verimli bir çalışma şekli beklenen hedeflere ulaşmada önemli bir kriterdir. Ancak bireylerin yaptıkları işten tatmin olmaları işin özellikleri gibi pek çok nedene bağlı olabilir. Çalışanların kişilik özelliklerinin onların tüm yaşamları üzerinde etkili olduğu gibi iş yaşamlarında ve örgütsel faaliyetler üzerinde de etkili olabileceği değerlendirilmektedir. 
İş Bağımsızlığının İşin Kendisinden Duyulan Tatmin Üzerindeki Etkisinde

Gelişime Açıklık Kişilik Özelliğinin Aracılık Rolü: Özel Sektörde Bir Uygulama

\section{Kuramsal Çerçeve}

Örgütlerde çalışanların yaptıkları iş, yaşamlarının önemli bir bölümünü kapsar. İnsanlar uyanık geçirdiği zamanlarının çoğunu mesleklerini icra ederek, iş yerinde geçirir. Bu nedenle çalışanların yaptıkları işin özellikleri ve tüm boyutları onların yaşantılarını tümüyle etkileme potansiyeline sahiptir (Çakıcı vd., 2013). İnsan yaptığı işten hoşnut değilse umutsuzluk, yaşamının başka alanlarına da ulaşır (Moore, 2009:4). Ayrıca işten hoşnutsuzluk ileride kişiye depresyon teşhisi konulmasına ilişkin önemli risk faktörlerinden biridir (Rath ve Harter, 2013:13). Dolayısıyla insanların yaptığı işi sevmesi gerekir. Yüksek düzeyde meslek esenliğine sahip kişilerin hayatlarında genellikle başarılı olmalarının olasılığı o durumda bulunmayanların ihtimalinden iki kat daha fazladır (Rath ve Harter, 2013:8). Bu kapsamda işin doğası ve içeriği, diğer bir ifadeyle iş özelliklerinin insanların işini sevmesinde en önemli etkenlerden birini oluşturduğu söylenebilir.

İş motivasyonu ve iş doyumunu birlikte açıklayan endüstri ve örgüt psikolojisi kuramlarının başında gelen “İş Özellikleri Kuramı”, 1950'li ve 1960'lı yıllarda iş genişletme ve iş zenginleştirme konularının çalışanlar üzerindeki etkilerini belirlemeye yönelik yapılan çalışmaların bir sonucu olarak Hackman ve Oldham (1975) tarafindan ileri sürülmüştür (Bilgiç, 2008: 67; Utaş, vd., 2017: 4). İş özellikleri kuramında, iş yerinde çalışanın kalitesine ve sahip olduğu iş tecrübesine uygun değişimler yapılarak işin yeniden tasarlanması ve çalışanın verimliliğinin artırılması amaçlanmaktadır. Kurama göre işin ana boyutları; beceri çeşitliliği, görev bütünlüğü, görevin önemi, özerklik ve geribildirimdir (Aşan, 2000: 104; Kaş11, 2007:162-163; Bilgiç, 2008: 68-69; Nicholson, 2010). Beceri çeşitliliği, işin ne derece farklı beceri ve yetenek gerektirdiğinin, kişinin işi yaparken ne kadar çeşitli faaliyetlerde bulunduğunun ölçüsüdür. Bir işin beceri çeşitliliği özelliği ne kadar yüksek ise; bu işi yapan çalışanın sahip olduğu nitelikleri de o derece fazla ve ustaca kullanması gerekir (Utaş vd., 2017: 9). Görev bütünlüğü, bir işin tamamının ya da tamamlanabilir bir parçasının başlangıcından bitimine kadar bir kişi tarafından tamamlanma derecesidir. Görevin önemi, yapılan işe toplum tarafından ve diğer çalışanlar tarafından verilen değerin ölçüsüdür. İşin değerli görülmesi çalışanların işlerini anlamlı bulmalarını sağlamaktadır. Özerklik, çalışanın işiyle ilgili kararlara katılabilmesi, yaptığı işte bağımsız olarak 
çalışabilmesi, işiyle ilgili inisiyatif alabilme derecesidir. Geri bildirim ise işin kendisinin, bireysel başarısına dair kişiye ne derecede açık ve doğrudan bilgi sağladığının ölçüsüdür. Burada geri bildirim dolaysız olarak işin kendisinden elde edilmiş olmalıdır. Hackman ve Oldham'ın ifade ettiği beş temel iş özelliğinden beceri çeşitliliği, görev bütünlügü ve görevin önemini kapsayan işin anlamlılı̆̆g ara değişkenini, özerklik işin sonuçlarından sorumlu olma ara değişkenini ve geri bildirim ise iş faaliyetleri sonuçlarına ilişkin bilgi ara değişkenini oluşturmaktadır (Utaş vd., 2017: 10).

İşin özelliklerinin alt boyutlarından biri olan işin bağımsızlığı, işin yapılmasına ilişkin prosedürlerin belirlenmesinde ve işin yapılma süreci içerisindeki muhtemel karar noktalarında çalışana özgürlük, bağımsızlık ve takdir hakkını kullanma yetkisinin verilmesidir (Gannon, 1979:184). Özerklik olarak da ifade edilen işin bağımsızlığı örgüt kaynaklarının çalışanlar tarafından kullanımı ve girişimleri gerçekleştirmek için cesaretlendirilmeleri olarak da ifade edilmektedir (Pekdemir, vd., 2014: 333). İş bağımsızlığı çalışanlara yapacakları işleri planlama, programlama ve belirlenen amaçları elde etmek için kullanılacak yol, yöntem ve metotları belirleme özgürlüğü olarak ifade edilmektedir (Morgeson, vd., 2005: 399).

İş tatmini, işin özelliklerinin değerlendirilmesi sonucu oluşan iş hakkındaki olumlu hissi ifade eden bir kavramdır (Robbins ve Judge, 2012:77). İş tatmini, işin özellikleriyle çalışanların istekleri birbirine uyduğu zaman gerçekleşen ve çalışanın işinden hoşnutluk duymasını belirleyen bir olgudur (Yiğit vd., 2011). Çalışanların iş tatmini arttıkça işin niteliği ve örgüte olan katkısı da artmaktadır (Çevik ve Korkmaz, 2014).

İnsanların haz duyduğu, tatmin olduğu durumlar karşısında olumlu tutumlar sergileyeceği inkâr edilemez bir gerçektir. İş tatmini de hem yönetim uygulamalarında davranış bilimleri açısından hem de psikoloji alanında uzun yıllar ilgi uyandırmış önemli bir konu olarak karşımıza çıkmaktadır (Özkalp ve Kırel, 2001:129; Ishfaq vd., 2011:228). İş tatmini çok farklı şekillerde tanımlanmakla birlikte, iş tatmininin tanımı konusunda iki farklı yaklaşım olduğu görülmektedir. Bazı araştırmacılar iş tatminini bir kişinin işinin özelliklerini değerlendirmesi sonucu oluşan işi hakkındaki olumlu duyguları olarak tanımlarken (Robbins ve Judge, 2012:77), bazı araştırmacılar da iş tatminini işgörenlerin işten elde 
İş Bağımsızlığının İşin Kendisinden Duyulan Tatmin Üzerindeki Etkisinde

ettiklerine karşı gösterdikleri tepki (Gordon, 2011:191) olarak tanımlamıştır. İş tatmini konusunun bu kadar fazla ilgi görmesinin nedeni, iş tatmininin yüksek verimlilik, düşük devamsızlık ve düşük işgücü devir oranı gibi örgüt tarafından da arzu edilen sonuçları doğurmasından ileri gelmektedir. Çünkü çalışanlar işlerinden elde etmesi gerektiği oranda tatmin elde edemiyorsa yaptığı işten zevk almamaya ve işinden uzaklaşmaya başlar ve bunun sonucunda günlük yaşantısında tatminsizlik etkili olurken çalışan genel bir mutsuzluk ortamına doğru sürüklenir (Weiss, 2002). Nitekim iş tatmininin, performans, örgütsel vatandaşlık (Le Pine vd., 2002), müş̧eri tatmini (Koys, 2001), devamsızlık, işgücü devri (Shalley vd., 2000; Bayrak Kök, 2006), çatışma, yabancılaşma gibi birçok kavramla yakından ilgili olduğu ifade edilmektedir. Bu kavramlar sadece bireyi değil, örgütü de doğrudan etkilemekte ve iş tatmininin göz ardı edilemeyecek kadar önemli olduğunu göstermektedir.

İş tatmininin çalışan tutumlarının genel sonucu olduğu ve çalışanın fiziksel ve zihinsel açıdan iyi durumda olmasını ifade ettiği (Oshagbemi, 2000a:88), çalışanın işine karşı olan genel tutumu olarak da (Greenberg ve Baron, 2000:170) ifade edilmiştir. Çalışanlar işlerine karşı olumlu veya olumsuz tutumlar gösterebilir. Bu nedenle iş tatmini çalışanların yaptıkları işin sonunda elde ettikleri olumlu ruhsal durumun yanında olumsuz ruhsal durumun da dikkate alınması gerekmektedir. İş tatmini çalışanların yaptıkları işe karşı hissettikleri duygu olarak ifade edilebilir (Sevimli ve İşcan, 2005:55). İş tatmini ancak çalışanların beklentilerinin karşılanması durumunda ortaya çıkabilir.

İş tatmininin iş bağımsızlığ uygulama firsatı, sorumluluk duygusu, sosyal statü gibi işin kendisinden duyulan tatminin derecesini ifade eden içsel tatmin ile işin kendisi ile doğrudan ilgisi olmayan, çalışma koşulları, politikalar, övgü ve takdir edilme gibi dışsal tatminin unsurlarından oluştuğu (Chen ve Chiu, 2005: 527-528) ifade edilmiştir (Mert, 2011; 123).

Kişilik, bireyin kendine özgü ve ayırıcı davranışlarının bütünüdür. Kişilik, bireyin belli bir süreçte ortaya koyduğu tutarlı davranış kalıplarıdır (Tutar, 2012: 84-85). Bu kapsamda kişilik, bireyleri birbirinden ayıran özellikler bütünüdür. Yöneticilerin kişiliği neden ve nasıl ölçeceklerini bilmeye ihtiyaçları vardır. Çünkü araştırmalar kişilik testlerinin istihdam kararlarını almada ve yöneticilerin bir iş 
için en iyi kimin olduğunu tahmin etmede faydalı olduğunu göstermiştir (Robbins ve Judge, 2012:135). Birçok psikolog, bireyin kişiliğinin temel yapısının beş boyuttan oluştuğuna inanmaktadır. $\mathrm{Bu}$ boyutlar; dişa dönüklük, uyumluluk, sorumluluk, gelişime açıklık ve duygusal istikrar. Bu boyutların hepsinin iş performansıyla çok yakından ilişkisi olduğu birçok araştırma ile ortaya konmuştur (Zel, 2011:25; Baysal ve Tekarslan, 2004:129). Bu boyutlardan; dışa dönüklük boyutu, kişinin kendine duyduğu güven, dış çevresi ile ilişkilerindeki rahatlık seviyesi ile ilgilidir. Dışa dönük bir birey, kendini ifade edebilen, sosyal bir kişidir. Uyumluluk boyutu, bir kişinin diğer kişilerle işbirliğine yatkınlığını ve diğer kişilere uyma eğilimi ile ilgilidir. Uyumlu bireyler, işbirlikçi, sıcak ve güvenilirdir. Sorumluluk boyutu, kişinin iş disiplinine ve hatta yaşamında karşısına çıkan işlere verdiği öneme atıfta bulunur. Sorumlu bir birey, düzenli, güvenilir ve azimlidir. Gelişime açıklık boyutu, bireyin hayal gücü, ileri görüşlülüğü ve değişme adaptasyonu ve esnekliği ile ilgilidir. Deneyime açık bireyler, yaratıcı ve meraklıdır. Duygusal istikrar boyutu ise bireyin olaylar karşısında duygularını kontrol edebilmesi ve verdiği tepkilerin tutarlılığını ifade etmektedir.

Gelişime açıklık boyutu yüksek olan çalışanlarda meraklı olma, yaratıcılık, hayal gücü, orijinallik, farklı olma gibi kişilik özellikleri ön plana çıkarken (Costa vd., 1986), aynı zamanda bu çalışanlar başkalarının duygu ve düşünceleri ile ilgilenen, yenilikleri takip eden bireylerdir. McCrae ve Costa (1991) gelişime açıklık boyutunun hayal gücü yüksek, sanatsal ve estetik olaylardan etkilenen, duygusal olarak hassas, çeşitlilik ve yeniliklere açık, entelektüel açıdan meraklı, analitik düşünen ve hoşgörülü ve açık fikirli olma gibi özelliklerden oluştuğunu ifade etmiştir. Buna karşın gelişime açıklık boyutu düşük olan çalışanların gelenekçi, faydacı, dar ilgi alanları olan, sanat ve estetik karşısında duyarsız, standartları takip eden ve dogmatik kişiler oldukları düşünülebilir (Yaşin, 2016; 41).

İşin bağımsızlığı, işten tatmin olma alt boyutlarından işin kendisinden tatmin olma durumu ile yakından ilişkilidir. İş özellikleri, iş tatmininde önemli bir etken olmakla birlikte işin, çalışanın kişilik özelliklerine de uygun olması gerekir. Kişilik, bireyi diğerlerinden ayıran zihinsel, duygusal ve davranışsal özellikler olarak tanımlanır (Baysal ve Tekarslan, 2004:101). Kişilik, çalışanların işyerindeki davranış şekilleri ile işlerine ve işyerlerine karşı geliştirdikleri tutumları açıklayan 
İş Bağımsızlığının İşin Kendisinden Duyulan Tatmin Üzerindeki Etkisinde

en önemli faktördür (George ve Jones, 2012:38). Kişiliğin; kariyer seçimi, iş tatmini, stres, liderlik ve iş performansı ile ilgili bazı hususları etkilediği belirtilmektedir (George ve Jones, 2012:39). Kişilik özellikleri ile uyumlu işler yapmak iş tatminini artırırken, kişilik özellikleri ile uyumlu olmayan işler iş tatminini düşürebilir (Tutar, 2014:168).

İş özelliklerinden işin bağımsızlığa imkân vermesi boyutuyla iş tatmini boyutlarından işin kendinden tatmin olma boyutu arasındaki ilişki incelendiğinde bağımsızlığa verilen önem arttıkça iş tatminin de arttığı belirlenmiştir (Gökdeniz ve Merdan, 2016:117). Benzer bir çalışmada akademik personelin işini yaparken bağımsız hareket edebilme olanağına sahip olmalarının iş tatminleri üzerinde olumlu yönde etkisinin olduğu belirtilmiştir (Tuzcu, 2016: 194).

Örgütlerde mevcut gelişim kültürünün çalışanların iş tatminleri üzerinde etkisi olduğu (Akkoç, vd., 2012:105) belirtilmiştir. Gelişme imkânları, çalışanların örgüt içinde kişisel gelişimlerini sağlamak amaciyla ne tür olanaklara sahip olduklarını değerlendirmeleri ile ortaya çıkar. Çalışanlar örgütlerini yeni şeyler öğrenebilecekleri bir "okul” olarak görmek isterler (Tuzcu, 2016: 168). Yaşin (2016: 129) yaptığı çalışmada gelişime açıklık boyutuyla iş tatmini arasında deneyime açıklık durumunun çalışanların iyi veya kötü deneyimlerinden ötürü olumlu veya olumsuz düşünceye sahip olmaları nedeniyle bir ilişkiye ulaşamadığını belirtmiştir.

\section{Yöntem}

Araştırmada iş özelliklerinde işin bağımsızlığa imkân vermesi boyutu ile iş tatmini boyutlarından işin kendisinden duyulan tatmin boyutu arasındaki ilişki ile bu ilişkide kişilik özelliklerinden gelişime açıklık boyutunun aracılık etkisinin incelenmesi amaçlanmıştır. İşin bağımsızlığa imkân vermesi boyutu bağımsız değişken, işin kendisinden duyulan tatmin boyutu bağımlı değişken olarak, gelişime açıklık boyutu ise aracı değişken olarak alınmıştır.

Çalışmanın amacını gerçekleştirmek üzere hazırlanan soru formları savunma sanayiinde özel sektörde İstanbul'da faaliyet gösteren 17 işletmede uygulanmıştır. Çalışanlara soru formları dağıtılmış, formların doldurulmasına yönelik gerekli açıklamalar yapılmış ve kendilerinin bizzat doldurmaları takip 
edilmiştir. Araştırmaya katılan örgütlerde toplam çalışan sayısı 1078'dir. Örgütlere çalışan sayısı kadar anket formu dağıtılmış olup toplam 649 anket doldurulmuştur. Geri dönüşüm oranı \%60'tır. Soru formları toplandıktan sonra yapılan değerlendirme sonucunda 27 adet anket formunun uygun doldurulmadığ tespit edilmiş ve analizlere dahil edilmemiştir. Analize dâhil edilen katılımcı sayısı 622 'dir. İşletmelere göre anket katılımcı durumu Tablo 1'de sunulmuştur.

Tablo 1: İşletmelere Göre Anketlerin Dağılımı

\begin{tabular}{|c|c|c|c|c|}
\hline İşletme & $\begin{array}{c}\text { Ulaşılan Çalışan } \\
\text { Sayısı }\end{array}$ & $\begin{array}{c}\text { Geri Dönen Anket } \\
\text { Sayısı }\end{array}$ & $\begin{array}{c}\text { Hatalı Anket } \\
\text { Sayısı }\end{array}$ & $\begin{array}{c}\text { Kullanılan Anket } \\
\text { Sayısı }\end{array}$ \\
\hline A & 46 & 31 & 1 & 30 \\
\hline B & 119 & 66 & 3 & 63 \\
\hline $\mathrm{C}$ & 48 & 21 & 1 & 20 \\
\hline $\mathrm{D}$ & 101 & 49 & 1 & 48 \\
\hline $\mathrm{E}$ & 44 & 26 & & 26 \\
\hline $\mathrm{F}$ & 107 & 76 & 2 & 74 \\
\hline $\mathrm{G}$ & 66 & 51 & 3 & 48 \\
\hline $\mathrm{H}$ & 77 & 60 & 4 & 56 \\
\hline I & 74 & 58 & 5 & 53 \\
\hline$\dot{\mathrm{I}}$ & 71 & 41 & 2 & 39 \\
\hline $\mathrm{J}$ & 73 & 43 & & 43 \\
\hline $\mathrm{K}$ & 38 & 21 & 1 & 20 \\
\hline $\mathrm{L}$ & 27 & 20 & 2 & 18 \\
\hline $\mathrm{M}$ & 62 & 31 & 1 & 30 \\
\hline $\mathrm{N}$ & 56 & 21 & & 21 \\
\hline $\mathrm{O}$ & 51 & 22 & 1 & 21 \\
\hline $\mathrm{P}$ & 18 & 12 & & 12 \\
\hline TOPLAM & 1078 & 649 & 27 & 622 \\
\hline
\end{tabular}

Verilerin toplanmasında üç ayrı ölçekten yararlanılmıştır. İş özellikleri ölçeği; Hackman ve Oldham (1974) tarafindan geliştirilen, beş temel iş özelliğini (işin yetenek çeşitliliği, bütünlüğü, önemi, bağımsızlığı ve geri bildirim durumu) birer ölçüm faktörü olarak ele alan bu ölçeğin "işin bağımsızlığa imkân vermesi" boyutunu ölçen üç maddesi kullanılmıştır. Ölçek yedi dereceli Likert tarzı bir ölçektir (1= Çok yanlış, 4= Kararsızım, 7= Çok doğru). 
İş Bağımsızlığının İşin Kendisinden Duyulan Tatmin Üzerindeki Etkisinde Gelişime Açıklık Kişilik Özelliğinin Aracılık Rolü: Özel Sektörde Bir Uygulama

İş tatmini ölçeği; Schneider ve Dachler (1978) tarafindan geliştirilen Türkçe çevirisi Ergin (1997), geçerlik ve güvenirlik çalışması Toker (2007) tarafindan yapılan bu ölçeğin "işin kendisinden duyulan tatmin" boyutunu ölçen dört maddesi kullanılmıştır. Ölçek beş dereceli Likert tarzı bir ölçektir (1= Hiç memnun değilim, $5=$ Çok memnunum).

Kişilik ölçeği; Lewis R. Goldberg (1992) tarafindan geliştirilen ve kişiliğin beş temel özelliğini içeren bu ölçeğin "deneyimlere açık olma" boyutunu ölçen 10 maddesi kullanılmıştır. Ölçek beş dereceli Likert tarzı bir ölçektir (1= Kesinlikle katılmiyorum, 5= Tamamen katıliyorum).

Katılımcıların demografik özelliklerinin tespitinin ardından, değişkenlere ilişkin verilerin ortalamaları, standart sapmaları ve aralarındaki korelasyon incelenmiştir. İşin bağımsızlığa imkân vermesi ile işin kendisinden tatmin olma arasındaki ilişkide kişiliğin deneyimlere açık olma özelliğinin aracılık rolünü belirlemek maksadıyla Baron ve Kenny (1986)'nin önerdiği dört aşamalı yaklaşım kullanılmıştır.

$\mathrm{Bu}$ kapsamda; araştırmanın ilk aşamasında iş özelliklerinin (İşin bağımsızlığa imkân vermesi boyutu) iş tatmini (İşin kendisinden duyulan tatmin boyutu) üzerindeki etkisi incelenmiştir. İkinci aşamada ise iş özellikleri ile iş tatmini arasındaki ilişkide kişiliğin (Gelişime açık olma) aracılık rolü araştırılmış ve araştırmanın modeli Şekil 1'de verilmiştir.

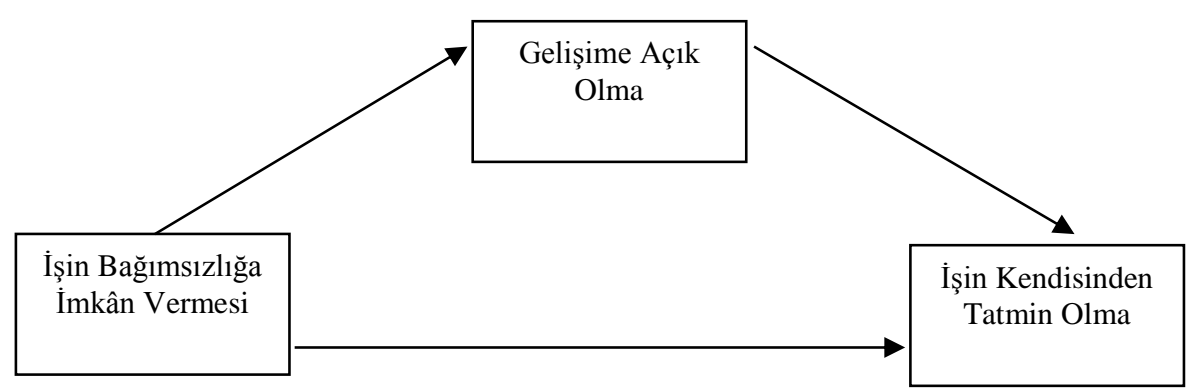

Şekil 1: Araştırmanın Modeli 
Araştırma hipotezleri şu şekilde ifade edilmiştir:

H1:.İsin bağımsızlığa imkân vermesi, işin kendisinden tatmin olma üzerinde olumlu bir etkiye sahiptir.

H2:.Gelişime açık olma kişilik özelliği, işin kendisinden tatmin olma üzerinde olumlu bir etkiye sahiptir.

H3:.Gelişime açık olma kişilik özelliğinin, işin bağımsızlığa imkân vermesi ile işin kendisinden tatmin olma ilişkisinde aracılık rolü vardır.

\section{Bulgular}

Araştırmaya katılanların; \%22.3'ü kadın, \%77.7'si erkektir. \%50.6'sı evli, \%49.4'ü bekârdır. Yaş ortalaması 31.9 (ss= 8.12)'dur. Katılımcıların eğitim durumları; \%7.6'sı ortaokul, \%14.8'i lise, \%11.7'si ön lisans, \%52.1'i üniversite ve \%13.8'i lisansüstü şeklindedir. Ortalama çalışma süresi 6 yıldır.

Analiz sonucunda elde edilen ortalamalar, standart sapmalar ve korelasyon değerleri Tablo 2'de verilmiştir.

Tablo 2: Değişkenlere Ait Ortalama, Standart Sapma ve Korelasyon Değerleri $(\mathrm{N}=622)$

\begin{tabular}{|l|c|c|c|c|c|}
\hline \multicolumn{1}{|c|}{ Değişkenler } & Ort. & s.s. & $\mathbf{1}$ & $\mathbf{2}$ & $\mathbf{3}$ \\
\hline İşin bağımsızlığa imkân vermesi & 4.17 & 1.04 & - & & \\
\hline Gelişime açık olma & 3.70 & .51 & $.093^{*}$ & - & \\
\hline İşin kendisinden tatmin olma & 5.46 & 1.35 & $.269^{* *}$ & $.180^{* *}$ & - \\
\hline
\end{tabular}

Bağımsız değişken ile bağımlı değişken arasında, bağımsız değişken ile aracı değişken arasında anlamlı bir ilişki olduğu görülmüştür. Korelasyon analizi neticesinde; iş özellikleri (İşin bağımsızlığa imkân vermesi) ile iş tatmini (İşin kendisinden tatmin olma) arasında $(\mathrm{r}=.269 ; \mathrm{p}<.01)$, iş özellikleri (İşin bağımsızlığa imkân vermesi) ile kişilik (Gelişime açık olma) arasında ( $\mathrm{r}=.093$; $\mathrm{p}<.05)$, kişilik (Gelişime açık olma) ile iş tatmini (İşin kendisinden tatmin olma) arasında ( $\mathrm{r}=.180$; $\mathrm{p}<.01)$ pozitif yönlü anlamlı bir ilişki tespit edilmiştir. $\mathrm{Bu}$ sonuçlara göre değişkenler arasında önemli ve anlamlı düzeyde etki olabileceği de öngörülebilir. 
İş Bağımsızlığının İşin Kendisinden Duyulan Tatmin Üzerindeki Etkisinde Gelişime Açıklık Kişilik Özelliğinin Aracılık Rolü: Özel Sektörde Bir Uygulama

Verilerin analizi kapsamında modelde çoklu doğrusal bağlantı (multicollinarity) sorunu olup olmadığına bakılmıştır. Elde edilen Tolerance ve VIF değerleri bağımsız değişkenler arasında çoklu bağlantı olmadığını doğrulayan sonuçlar vermiştir (Tolerance $>.2 ; \mathrm{VIF}<10$ ).

Aracı etki analizi için Baron ve Kenny (1986) tarafından önerilen dört aşamalı hiyerarşik regresyon analiz yöntemi kullanılmıştır. Regresyon analiz sonuçları Tablo 3’te gösterilmiştir.

Tablo 3: Regresyon Analiz Sonuçları $(\mathrm{N}=622)$

\begin{tabular}{|c|c|c|c|c|c|c|}
\hline \multirow{2}{*}{ Adımlar } & \multirow{2}{*}{$\begin{array}{l}\text { Bağımsız } \\
\text { Değişken }\end{array}$} & \multirow{2}{*}{$\begin{array}{c}\text { Bağımlı } \\
\text { Değişken }\end{array}$} & \multicolumn{3}{|c|}{ Regresyon Katsayıları } & \multirow{2}{*}{$\begin{array}{c}\text { Model } \\
\text { İstatistikleri }\end{array}$} \\
\hline & & & $\mathbf{B}$ & S.H. & $\boldsymbol{\beta}$ & \\
\hline 1.Adım & $\begin{array}{l}\text { İ̀sin } \\
\text { bağımsızlığa } \\
\text { imkân vermesi }\end{array}$ & $\begin{array}{l}\text { İşin } \\
\text { kendisinden } \\
\text { tatmin olma }\end{array}$ & .351 & .051 & $.269 * *$ & $\begin{array}{l}\mathrm{R}^{2}=.072 \\
\mathrm{~F}_{(1,620)}=48.204\end{array}$ \\
\hline 2.Adım & $\begin{array}{l}\text { İşin } \\
\text { bağımsızlığa } \\
\text { imkân vermesi }\end{array}$ & $\begin{array}{l}\text { Gelişime } \\
\text { açık olma }\end{array}$ & .045 & .020 & $.093 *$ & $\begin{array}{l}\mathrm{R}^{2}=.009 \\
\mathrm{~F}_{(1,620)}=5.351\end{array}$ \\
\hline 3.Adım & $\begin{array}{l}\text { Gelişime açık } \\
\text { olma }\end{array}$ & $\begin{array}{l}\text { İşin } \\
\text { kendisinden } \\
\text { tatmin olma }\end{array}$ & .476 & .105 & $.180 * *$ & $\begin{array}{l}\mathrm{R}^{2}=.032 \\
\mathrm{~F}_{(1,620)}=20.679\end{array}$ \\
\hline \multirow{2}{*}{ 4.Adım } & $\begin{array}{l}\text { İşin } \\
\text { bağımsızlığa } \\
\text { imkân vermesi }\end{array}$ & İşin & .332 & .050 & $.254 * *$ & \multirow{2}{*}{$\begin{array}{l}\mathrm{R}^{2}=.096 \\
\mathrm{~F}_{(2,619)}=32.986\end{array}$} \\
\hline & $\begin{array}{l}\text { Gelişime açık } \\
\text { olma }\end{array}$ & tatmin olma & .414 & .102 & $.156^{* *}$ & \\
\hline
\end{tabular}

Tablo 3'teki veriler incelendiğinde; işin bağımsızlığa imkân vermesi ile işin kendisinden tatmin olma arasındaki ilişkinin pozitif ve anlamlı olduğu ( $\beta=.269$; $\mathrm{p}<.01)$ görülmüsstür. Böylece H1 hipotezi kabul edilmiştir. Yine gelişime açık olma kişilik özelliğinin işin kendisinden tatmin olma üzerinde olumlu bir etkiye sahip olduğu görülmüştür $(\beta=.180 ; p<.01)$. Böylece $\mathrm{H} 2$ hipotezi de kabul edilmiştir. 
Gelişime açık olma kişilik özelliğinin, işin bağımsızlığa imkân vermesi ile işin kendisinden tatmin olma ilişkisinde aracılık rolünün olup olmadığını belirlemek için yapılan dört aşamalı regresyon analizinin sonuçları şu şekildedir: Birinci adımda iş özelliklerinin iş tatmini üzerinde pozitif yönlü ve anlamlı bir etkisinin olduğu $(\beta=.269 ; \mathrm{p}<.01)$, ikinci adımda iş özelliklerinin kişilik üzerinde pozitif yönlü ve anlamlı bir etkisinin olduğu $(\beta=.093 ; p<.05)$, üçüncü adımda kişiliğin iş tatmini üzerinde pozitif yönlü ve anlamlı bir etkisinin olduğu ( $\beta=.180$; $\mathrm{p}<.01)$ tespit edilmiştir. Dördüncü adımda iş özellikleri ve kişiliğin iş tatmini üzerindeki etkilerine bakıldığında; iş özelliğinin iş tatmini üzerinde pozitif yönlü ve anlamlı bir etkisinin olduğu $(\beta=.254 ; p<.01)$, yine kişiliğin iş tatmini üzerinde pozitif yönlü ve anlamlı bir etkisinin olduğu $(\beta=.156 ; p<.01)$ bulunmuştur.

Aracılık etkisinden bahsedebilmek için aracı değişkenin varlığının, bağımlı değişken üzerinde bağımsız değişkenin direkt etkisini azaltması gerekir. Bu kapsamda yukarıda verilen bulgular iş özellikleri ile iş tatmini arasında kişiliğin aracılık rolü olduğunu göstermiştir. Bu şartların sağlanmasının ardından aracılık etkisini teyit etmek maksadıyla Sobel testi yapılmış, Sobel testinin hesaplanması neticesinde aracılik etkisi istatistiksel olarak anlamlı bulunmuştur $(\mathrm{z}=2.0154$; $\mathrm{p}<.05$ ). Bu bulgu iş özelliklerinin (İşin bağımsızlığa imkân vermesi) iş tatmini (İşin kendisinden tatmin olma) etkisinde kişiliğin (Gelişime açık olma) aracılık rolü üstlendiğini göstermektedir. Böylece $\mathrm{H} 3$ hipotezi kabul edilmiştir.

\section{Sonuç}

Çalışanların işlerinden tatmin olması hem kendileri hem de örgütleri için önemli bir konudur. İş tatmini çalışanlar için örgütlerine yapabilecekleri katkıların başlangıç noktasını oluşturmaktadır. Çalışanların işlerinden tatmin olmaları olumlu pek çok tutum ve davranışın ortaya çıkmasını sağlar. Bu nedenle iş tatmininin iş özellikleri ile yakından ilişkili olduğu ifade edilebilir. Birçok bireyin çalışmaktan hoşlanmasının nedenleri arasında yaptıkları işin anlamlı olması, işinin bilgisini ve zekâsını kullanmayı gerektirmesinden kaynaklandığı düşünülebilir. Bu da bireyin yaptığı işte inisiyatif kullanabilmesi ile mümkündür. İşin yapılmasına ilişkin prosedürlerin belirlenmesinde ve işin yapılma süreci içerisindeki muhtemel karar noktalarında çalışana özgürlük, bağımsızlık ve takdir hakkını kullanma 
İş Bağımsızlığının İşin Kendisinden Duyulan Tatmin Üzerindeki Etkisinde

yetkisinin verilmesi, çalışanın da bu yetkileri kullanma konusunda istekli olması ile iş tatmini daha çok artacaktır. Dolayısıyla iş özelliklerinin yanında kişilik özellikleri de iş tatmini konusunda önemli bir unsur olarak değerlendirilmelidir.

Yapılan bu çalışmada iş özelliklerinden işin bağımsızlığa imkân vermesi boyutu ile iş tatmini boyutlarından işin kendisinden duyulan tatmin boyutu arasındaki ilişki ile bu ilişkide kişilik özelliklerinden gelişime açıklık boyutunun aracılık etkisinin incelenmesi amaçlanmıştır.

Yapılan analizlerin neticesinde; birinci hipotez olan "İşin bağımsızlığa imkân vermesi, işin kendisinden tatmin olma üzerinde olumlu bir etkiye sahiptir." hipotezi, ikinci hipotez olan "Gelişime açık olma kişilik özelliği, işin kendisinden tatmin olma üzerinde olumlu bir etkiye sahiptir.” hipotezi kabul edilmiştir.

Üçüncü hipotez olan "Gelişime açık olma kişilik özelliğinin, işin bağımsızlığa imkân vermesi ile işin kendisinden tatmin olma ilişkisinde aracılık rolü vardır." hipotezi yapılan analiz neticesinde aracılık rolü olduğu tespit edildiğinden kabul edilmiştir. Böylece iş tatmini üzerinde işin özellikleri yanında kişiliğin de önemli bir unsur olduğu söylenebilir. Bu kapsamda, işin ne zaman ve nasıl yapılacağına mevcut şartlar dikkate alınarak çalışanın karar vermesi, kişisel inisiyatif kullanılması gereken durumlarda kullanmasına izin verilmesinin iş tatmini üzerinde olumlu etkileri olabileceği değerlendirilmektedir. İnisiyatif kullanmak işi benimsemek, işi kendi işi gibi kabul etmek anlamında çalışanlar için önemli bir tatmin aracı olduğu kadar risk içeren bir konudur. Bu nedenle inisiyatif kullanabilmek için zeki, kültürlü, orijinal ve yaratıcı fikirlere sahip çalışanların örgütlerde istihdamına önem verilmesinin daha uygun olabileceği ifade edilebilir.

Çalışmanın özel sektörde yapılması, sınırlı sayıda ve kolay ulaşılabilen çalışanlarla, belirli bir zaman diliminde yapılmış olması ve işletmelerin savunma sanayisinde faaliyet alanlarına göre sınıflandırılmaması çalışmanın kısıtları arasında sayılabilir. Daha sonra yapılacak çalışmaların savunma sanayisi farklı sektörlerde yapılması durumunda ve savunma sanayisinde yapılan çalışmalarda ise işletmelerin faaliyet alanlarına göre sinıflandırılarak yapılması halinde farklı sonuçlara ulaşılabileceği değerlendirilmektedir. İşin özellikleri, iş tatmini ve kişilik özelliklerinin diğer boyutları da kullanılarak çalışma genişletilerek literatüre katkı sağlayabilir. 


\section{Extended Summary}

\section{Introduction}

Business life is an important process that meets the varied needs of individuals and all employees spend a significant part of their time for organizations. For this reason, work life plays an important role in the life satisfaction of employees. The work itself and the characteristics of the job are important in the job satisfaction of the employees. In this study, it was aimed to determine the mediating role of the personality trait of being open to development on the effect of job independence, one job characteristics, on satisfaction from job itself, one of the dimensions of job satisfaction. The dimension of allowing independence of work is the independent variable, the satisfaction dimension of the work itself is taken as the dependent variable and the development openness dimension is taken as the mediating variable.

\section{Method}

The questionnaire form prepared for the research was applied to 17 private sector companies which operate in Istanbul. The number of employees of these organizations is 1078. Questionnaire forms were prepared as many as the number of employees and they were delivered to the employees. However, 622 questionnaires were used in the analysis.

Work Characteristics Scale used in this study was developed by Hackman and Oldham (1974). It is a seven-point Likert-style scale and three of the items which measure job independence are used. Job satisfaction scale was developed by Schneider and Dachler (1978) and it was translated in to Turkish by Ergin (1997), its validity and reliability study was conducted by Toker (2007). Scale is a fivepoint Likert-style scale. Four items of the scale which measure "satisfaction from the job itself" were used. Personality scale used in this study was developed by Lewis R. Goldberg (1992) and it contains five basic features of personality. Ten item of it which measures the dimension of being "open the experience" were used. The scale is a five-point Likert-style scale. 
İş Bağımsızlığının İşin Kendisinden Duyulan Tatmin Üzerindeki Etkisinde Gelişime Açıklık Kişilik Özelliğinin Aracılık Rolü: Özel Sektörde Bir Uygulama

\section{Analyzes and Findings}

After the demographic characteristics of the participants were determined, the mean of data on the variables, the correlation between the standard deviations and the variables were analyzed and regression analysis was performed to test the hypothesis.

As a result of the correlation analysis; between job characteristics (allowing independence of the job) and job satisfaction (satisfaction of the job itself) $(r=.269 ; p<.01)$, between job characteristics (allowing independence of the job) and personality (being open to development) $(r=.093 ; p<.05)$, and between personality (open to development) and job satisfaction (satisfaction from the job itself) (r=.180; $\mathrm{p}<.1)$ a positive-orientation relationship was determined.

According to these results, it can be suggested that there may be significant effects among variables. In the analysis of the data, the model has been examined whether there is a multi- collinerality problem. The obtained tolerance and VIF values yielded results that confirm that there are no multiple correlations between the independent variables (tolerance $>0.2 ; \mathrm{VIF}<10$ ).

A four-step hierarchical regression analysis method proposed by Baron and Kenny (1986) was used for tool Impact Analysis. The relationship between allowing independence and satisfaction of the job itself is seen positive and meaningful $(\beta=.269 ; p<.01)$. Thus, the H1 hypothesis was accepted. It has also been observed that the personality trait of being open to development has a positive effect on satisfaction from the job itself $(\beta=.180 ; \mathrm{p}<.01)$. Thus, the H2 hypothesis was accepted.

A four-step regression analysis was carried out to determine whether the personality feature of being open to development was a mediator in the relationship between allowing independence of job and the satisfaction of the job itself. In the first step, Job features have a positive and meaningful effect on job satisfaction $(\beta=.269 ; \mathrm{p}<.01)$, in the second step, job features have a positive and meaningful effect on personality $(\beta=.093 ; \mathrm{p}<.05)$, in the third step, personality has a positive and meaningful effect on job satisfaction $(\beta=.180 ; p<.01)$ detected. In the fourth step, looking at the effect of job characteristics and the effects of personality on the job satisfaction, the job characteristics have a positive and meaningful effect on the 
job satisfaction $(\beta=.254 ; \mathrm{p}<.01)$ and personality has been found to have a positive and meaningful effect on job satisfaction $(\beta=.156 ; p<.01)$.

In order to talk about the mediation effect, the existence of the intermediary variable must reduce the direct effect of the independent variable on the dependent variable. The findings show that personality plays a mediating role between job characteristics and job satisfaction. After these conditions were met, Sobel test was performed to confirm the intermediation effect. As a result of Sobel test calculation, the mediation effect was found statistically significant $(\mathrm{z}=2.0154$; $\mathrm{p}<.05$ ). This finding shows that the personality (open to development) plays a mediating role in the impact of job satisfaction (satisfaction from the job itself) on job characteristics (allowing the job to be independent). Thus, the $\mathrm{H} 3$ hypothesis was accepted.

\section{Conclusions}

At the end of the analyzes made, three hypotheses were accepted. Thus, it can be said that personality is an important factor besides job characteristics on job satisfaction. In this context, it is evaluated that when and how the work is done, it can be positive effects on the job satisfaction by allowing the employee to make decisions and to use them in situations where personal initiative should be used. Taking initiative is a risky issue, as it is an important satisfying tool for employees who are willing to accept it as their own business. For this reason, to use initiative, it can be said that it is more appropriate to give importance to the employment of the employees who have intelligence, culture, original and creative ideas.

\section{Kaynakça}

\section{Makaleler}

Aşan, Ö. (2000). İş Özellikleri Modelinde Kritik Psikolojik Hallerin Aracılık RolününTest Edilmesine Yönelik Ampirik Bir Çalışma. Amme İdaresi Dergisi, 33(2), 103-119.

Baron, R.M. ve Kenny, D.A. (1986). The Moderator Mediator Variable Distinction in Social Psychological Research: Conceptual, Strategic, and Statistical 
İş Bağımsızlığının İşin Kendisinden Duyulan Tatmin Üzerindeki Etkisinde

Gelişime Açıklık Kişilik Özelliğinin Aracılık Rolü: Özel Sektörde Bir Uygulama

Considerations. Journal of Personality and Social Psychology, 51, 11731182.

Bayrak Kök, S. (2006). İş Tatmini ve Örgütsel Bağl1lığın İncelenmesine Yönelik Bir Araştırma. İktisadi ve İdari Bilimler Dergisi, 20(1), 291-317.

Bilgiç, R. (2008). İş Özellikleri Kuramı: Geniş Kapsamlı Gözden Geçirme. Türk Psikoloji Yazıları, 11(22), 66-77.

Çakıc1, A., Özkan, C. ve Akyüz, B.H. (2013). İş Yükü Yoğunluğunun, İş ve Yaşam Doyumuna Etkisi Üzerine Otomotiv İşletmelerinde Bir Araştırma. Çağ University Journal of Social Sciences, 10(2), 1-27.

Çevik, N.K., ve Korkmaz, O. (2014). Türkiye'de Yaşam Doyumu ve İş Doyumu Arasındaki İlişkinin İki Değişkenli Sıralı Probit Model Analizi, Niğde Üniversitesi IIBBF Dergisi, 7(1), 126-145.

Ergin, C. (1997). Bir İş Doyumu Ölçümü Olarak İş Betimlemesi Ölçeği: Uyarlama, Geçerlik ve Güvenilirlik Çalışması. Türk Psikoloji Dergisi, 12(39), 25-36.

Gordon, V. (2011). Exploring the job Satisfaction of Municipal Clerks. Review of Public Personnel Administration, 31(2), 190-208.

Gökdeniz, İ., Medan E., (2016). Meslek Seçimi İle İş Tatmini İlişkisi: Bankacılık Sektöründe Bir Uygulama. Aksaray Üniversitesi İ̈BF Dergisi, 8(2), 111121.

Ishfaq A.,Usman, A. ve Rana, S.L. (2011). Jobs Satisfaction Mediates Relationship Between Facets of Job and Citizenship Behavior: A Study of Female Employees of Banking Sector of Pakistan. Information Management and Business Review, 3(4), 228-234.

Kaşl1, M. (2007). İş Özellikleri Modelinin Otel İşletmelerinde Uygulanabilirliğine Yönelik Bir Araştırma. Doğuş Üniversitesi Dergisi, 8(2), 159-174.

Koys, D.J. (2001). The Effects of Employee Satisfaction, Organizational Citizenship Behavior, and Turnover on Organizational Effectiveness: A Unit-level, Longitudinal Study. Personal Psychology, 54(1), 101-114.

LePine, J.A., Erez, A. ve Johnson, D.E. (2002). The Nature and Dimensionality of Organizational Citizenship Behavior: A Critical Review and Meta-Analysis. Journal of Applied Psychology, 87(1), 52-65. 
Mert, İ.S. (2011). İş Tatmini Alt Boyutlarının Örgütsel Vatandaşlık Davranışı Üzerindeki Etkisi: Yöneticiler Üzerine Bir Araştırma. KHO Bilim Dergisi, 117-143.

Morgeson, F.P., Klinger, K.D., Hemingway M.A., (2005). The Importance of Job Autonomy, Cognitive Ability, and Job-Related Skill for Predicting Role Breadth and Job Performance. Journal of Applied Psychology, 90(2), 399406.

Nicholson, N. (2010). The Design of Work-An Evolutionary Perspective. Journal of Organizational Behavior, 31, 423-424.

Oshagbem1, T. (2000). Satisfaction with Co-Workers' Behaviour, Employee Relations, 22(1), 88-106.

Pekdemir, I., Koçoğlu, M., Gürka, G.Ç., (2014). Özerklik ve Ödüllendirme Algılarının Çalışan Performansı Üzerindeki Etkisinde Çalışanın İnovasyona Yönelik Davranışının Aracılık Rolüne Yönelik Bir Araştırma. İstanbul Üniversitesi İsletme Fakültesi Dergisi 43(2), 332-350.

Sevimli, F., İşcan Ö.F. (2005). Bireysel ve İş Ortamına Ait Etkenler Açısından İş Doyumu. Ege Akademik Bakış, 5(12), 55-64.

Shalley, C.E., Gilson, L.L. ve Blum, T.C. (2000). Matching Creativity Requirements and the Work Environment: Effects on Satisfaction and Intentions to Leave. Academy of Management Journal, 43(2), 215-223.

Toker, B. (2007). Demografik Değişkenlerin İş Tatminine Etkileri: İzmir'deki Beş ve Dört Yıldızlı Otellere Yönelik Bir Uygulama. Doğuş Üniversitesi Dergisi, 8(1), 92-107.

Tuzcu, A. (2016). Ankara Üniversitesi Tömer'de Çalışan Akademik ve İdari Personelin İş Tatmin Düzeyinin ve İş Tatminine Etki Eden Faktörlerin Belirlenmesi. AÜ SBF Dergisi, 71(1), 161-197.

Utaş, T., Çinko, L., Işı1, G. (2017). Hibrit İş Özellikleri Kuramı Çerçevesinde İş Motivasyonu ve Üretim. Social Science Research Journal, 6(1), 1-21.

Yaşin, T., (2016). Kişilik Özellikleri Ve Psikolojik Sermayenin Psikolojik İyi Oluş, Akış Deneyimi, İş Tatmini ve Çalışan Performansına Etkileri. (Doktora Tezi). Başkent Üniversitesi SBE, Ankara.

Yiğit, R., Dilmaç, B. ve Deniz, M.E. (2011). İş ve Yaşam Doyumu: Konya Emniyet Müdürlüğü Alan Araştırması. Polis Bilimleri Dergisi, 13(3), 1-18. 
İş Bağımsızlığının İşin Kendisinden Duyulan Tatmin Üzerindeki Etkisinde

Weiss, H.M. (2002). Deconstructing Job Satisfaction: Separating Evaluations, Beliefs and Affective Experiences. Human Resource Management Review, 12, 173-194.

\section{Kitaplar}

Baysal, A.C. ve Tekarslan, E. (2004). Davranış Bilimleri, Genişletilmiş 4. Basım, İstanbul: Avciol Basım Yayın.

Gannon, M.J. (1979). Organizational Behavior: A Managerial and Organizational Perspective, Little, Brown and Company, Boston, Toronto.

George, J.M. ve Jones, G.R. (2012). Understanding and Managing Organizational Behavior, Pearson, USA.

Greenberg, J., Baron, R.A. (2000). Behavior in Organizations. Seventh Edition, Prentice Hall, New Jersey.

Moore, T. (2009). İş: Hayatın Kalbi. (Çev.: Çağla Yılmaz), İstanbul: İKÜ Yayınları.

Özkalp, E. ve Kırel, Ç. (2001). Örgütsel Davranış, Eskişehir: Anadolu Üniversitesi Yayınları.

Rath, T. ve Harter, J. (2013). Wellbeing Esenlik, (Çev.: Çağla Yılmaz), İstanbul: İKÜ Yayınları.

Robbins, S.P. ve Judge, T.A. (2012). Örgütsel Davranış. (Çev.Ed.: İnci Erdem), Ankara: Nobel Yayıncilık.

Tutar, H. (2012). Sosyal Psikoloji, Ankara: Seçkin Yayıncılık.

Tutar, H. (2014). Örgütsel Psikoloji, Ankara: Detay Yayınları.

Zel, U. (2011). Kişilik ve Liderlik, 3.Basım, Ankara: Nobel Yayıncılık.

\section{Web Sitesi}

Goldberg, L.R. (1992). International Personality Item Pool, http://ipip.ori.org Erişim Tarihi: 12.03. 2015. 